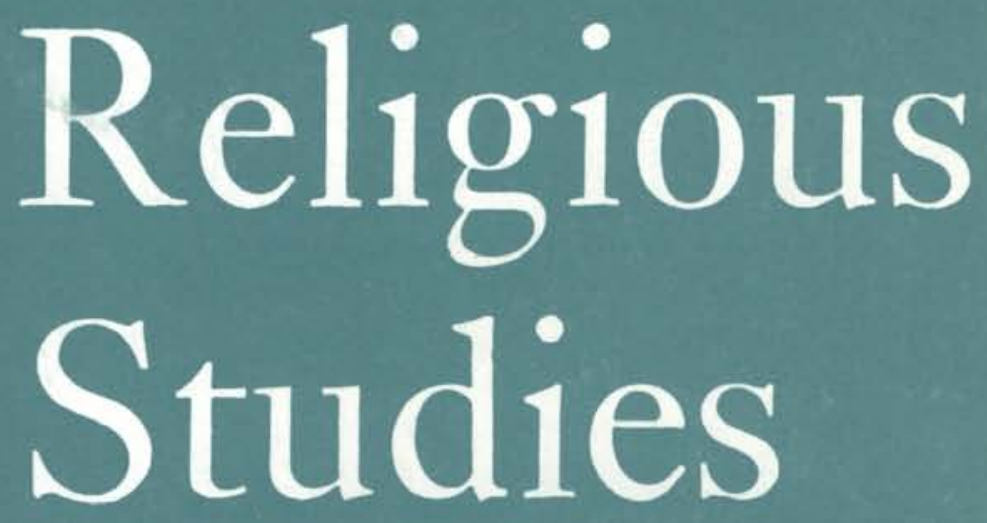

VOLUME 28 NUMBER 2 JUNE 1992

$0034-4125$

CAMBRIDGE UNIVERSITY PRESS 


\title{
Edilorial Board
}

\author{
Professor Vincent BRuMMer \\ Rev. Canon B. HeBblethwaite \\ PROFESSOR JOHN Hick \\ Professor URSULA KING \\ ProfESSOR N. L. A. LASH
}

Professor Alvin Plantinga

PROFESSOR N. SMART

Professor SteWARt SUTHERLAND

Professor R. G. SWINBURNe

\section{Editorial Advisers}

Professor Richard H. Bell, Department of Philosophy, The College of Wooster.

Professor M. Chatterjee, Department of Philosophy, University of Delhi.

Dr P. B. Clarke, Department of Theology \& Religious Studies, King's College, London.

Mr Michael Durrant, Department of Philosophy. University College of Cardiff:

Dr F. Hardy, Theology \& Religious Studies, King's College, London.
Dr G. M. Jantzen, Theology and Religious Studies, King's College, London.

Professor T. Penelhum, Department of Religious Studies, University of Calgary,

Dr P.J. Sherry, Department of Religious Studies, University of Lancaster.

Rabbi Dr Jonathan Sacks, Chief Rabbi's Office, London.

Dr C. Schwobel, Department of Theology \& Religious Studies, King's College, London.

The Editorial Office of Religious Studies is at Department of Theology \& Religious Studies, King's College, London.

Religious Studies is primarily concerned with the central problems of the philosophy of religion, as these arise out of classical and contemporary discussion and from varied religious traditions. The editors will also be happy to accept papers in other branches of the study of religions (e.g. psychology and sociology) where these are of general scholarly interest. The journal has no commitment to any specific school of philosophy, or denominational or confessional background. Space is reserved mainly for articles but there will also be extended book discussions, surveys of recent literature and book notes. It is hoped from time to time to publish replies to articles published in the journal and to provide in these and kindred ways a forum for debate of questions of importance in the study of religions today. Although authors will sometimes be encouraged to develop their views at some length the highest standards of precision and clarity are to be maintained.

\section{(C) Cambridge University Press 1992 \\ Copying}

This journal is registered with the Copyright Clearance Center, 27 Congress St., Salem, Mass. ot970. Organizations in the USA who are also registered with C.C.C. may therefore copy material (beyond the limits permitted by sections 107 and 108 of US copyright law) subject to payment to C.C.C. of the per copy-fee of $\$_{5}, 00$. This consent does not extend to multiple copying for promotional or commercial purposes, Code $0034-4125 / 92 \$ 5.00+.00$.

ISI Tear Sheet Service, 35ot Market Street, Philadelphia, Pennsylvania tgro4, USA, is authorized to supply single copies of separate articles for private use only.

For all other use, permission should be sought from Cambridge or the American Branch of Cambridge University Press.

\section{SUBSCRIPTIONS}

Orders, which must be accompanied by payment, may be sent to any bookseller or subscription agent, or direct to the publisher: Cambridge University Press, The Edinburgh Building, Shaftesbury Road, Cambridge CB2 2RU. Subscriptions in the USA and Canada should be sent to Cambridge University Press, The Journals Department, 40 West 2oth Street, New York, NY $10011-4211$, USA. Each volume of Religious Studies (ISSN $0034-4125$ ) is published in four parts, appearing in March, June, September and December. The subscription price, which includes postage, of Volume 28 ( 1992$)$ is $f 76.00 \mathrm{net}$ (US 5139.00 in the USA and Canada) for institurions; $£ 37.00$ (US $\$ 69.00$ in USA and Canada) for individuals ordering direct from the Press and certifying that the journal is for their personal use. Single parts are available at $£ 20.00$ (US $\$ 37.00$ in USA and Canada), plus postage.

Claims for non-receipt of copies will not be entertained if they are made more than four months after publication.

Second class postage paid at New York, NY, and at additional mailing offices. POSTMASTER: send address changes in USA and Canada to Religious Studies, Cambridge University Press, 1 to Midland Avenue, Port Chester, New York, NY 10573-9864. 